\title{
Feasibility of the immunohistochemical detection of endogenous steroids in paraffin-embedded ovarian tumours
}

\author{
S. CHADHA ${ }^{1}$, F. DE JONG ${ }^{2}$, C. C. J. VAN VROONHOVEN ${ }^{1}$ and TH. H. VAN DER \\ KWAST $^{1}$ \\ Departments of ${ }^{1}$ Pathology and ${ }^{2}$ Biochemistry, Erasmus University, 3015 GD Rotterdam, The Netherlands
}

Received 24 May 1989 and in revised form 7 November 1989

\begin{abstract}
Summary
Formalin-fixed, paraffin-embedded samples from 25 ovarian granulosa cell tumours and six poorly differentiated ovarian carcinomas were examined immunohistochemically for the presense of estradiol, testosterone and progesterone. Twentyfour of the 25 granulosa cell tumours stained for estradiol predominantly in granulosa cells and also in the theca cells, but none of the carcinomas were positive. All the granulosa cell tumours and five out of six carcinomas were positive for progesterone, while 13 granulosa cell tumours and three carcinomas stained moderately positive for testosterone.

No clear-cut relationship was observed between positivity for estradiol in granulosa cell tumours and occurrence of endometrial hyperplasia. In two cases of granulosa cell tumours, 1-15\% cells showed ultrastructural features of steroid synthesis: i.e. moderate to abundant smooth endoplasmic reticulum and mitochondria with tubular cristae. This is in contrast with the diffuse immunohistochemical staining reaction of granulosa cell tumours with antisteroid antibodies.

To evaluate the significance of immunohistochemical reactions for estradiol, four estradiol-containing tumours were tested by radioimmunoassay for the presence of estradiol before and after dehydration. As expected, treatment with organic solvents leads to a drastic reduction in estradiol content below the detection level of the assay. The results indicate that immunohistochemical staining for steroids of paraffin-embedded granulosa cell tumours is of limited value.
\end{abstract}

\section{Introduction}

Granulosa cell tumours are the most common type of ovarian neoplasms associated with endocrine manifestations: i.e. approximately three-quarters are accompanied by symptoms of hyperestrinism, leading to sexual pseudoprecocity before puberty and endometrial hyperplasia in older women (Young \& Scully, 1984; Fox, 1985). Rarely, granulosa cell tumours may be virilizing (Norris \& Taylor, 1969; Giuntoli et al., 1976; Wilansky, et al., 1976; Jarabak \& Talerman, 1983). Women with granulosa cell tumour are at a significantly higher risk of developing endometrial carcinoma which is also attributed to hyperestrinism (Fox et al., 1975; Scully, 1977a).

Localization of steroid hormones in ovarian gonadal stromal tumours has been extensively studied immunohistochemically by Kurman et al. (1978, 1979, 1984). These authors claimed that in granulosa-theca tumours estradiol is localized mainly in granulosa cells, suggesting that granulosa rather than theca cells are primarily responsible for estrogen in these tumours. Nishi et al. (1987) reported the detection of endogenous estradiol in a proportion of stomach cancers, employing an immunohistochemical technique on sections of paraffin-embedded tissues.

The aim of the present study was to assess the feasibility of immunohistochemical detection of steroids (estradiol, progesterone and testosterone) in paraffin-embedded material. Therefore, a number of these granulosa cell tumours were studied ultrastructurally, and the immunohistochemical results were correlated with the endometrial findings in the same patients. In addition, radioimmunoassay was performed on a number of freshly frozen, steroidcontaining tumours, before and after dehydration.

\section{Materials and methods}

\section{TISSUES}

From the files of the Dutch Ovarian Tumour Committee, 17 granulosa-theca cell tumours were retrieved. Eight cases of granulosa cell tumours and six cases of undifferentiated carcinoma, referred from the regional hospitals to the Rotterdam Radiotherapy Institute, were also included in our 
study. Clinical data and follow up were available in all cases. All specimens were formalin-fixed and routinely paraffinembedded in tissue blocks. The histological diagnosis was based on sections stained with Hematoxylin-azofloxin, using standard criteria (Scully, 1979).

Electron microscopy was performed on frozen tissue in two cases. In addition, frozen specimens from two granulosa cell tumours, one thecoma and one case of hyperthecosis were analysed by radioimmunoassay.

\section{ANTIBODIES}

The mouse monoclonal antibodies and rabbit antisera, used for immunohistochemical detection of steroids in the present study, are listed in Table 1 . In order to detect the binding of mouse monoclonal antibodies on tissue section, we applied the indirect conjugated method using a rabbit anti-mouse antiserum conjugated to horse-radish peroxidase (RAM-PO), purchased from DAKO, Denmark. The binding of rabbit antibodies was detected by horse-radish peroxidase conjugated to swine anti-rabbit antiserum (SWAR-PO), purchased from DAKO, Denmark.

\section{Immunohistochemistry}

Paraffin sections $5 \mu \mathrm{m}$ thick were deparaffinized in xylene and absolute ethanol. The endogenous peroxidase activity was blocked by incubation in methanol containing 3\% hydrogen peroxide for $30 \mathrm{~min}$ at room temperature. Before the application of primary rabbit antisera, reduction of nonspecific background staining was achieved by incubation of the sections with $20 \%$ non-immune swine serum (NSS) diluted in PBS for $15 \mathrm{~min}$. The sections were then overlaid with the appropriate dilutions of the primary antibodies for $1 \mathrm{~h}$ at room temperature, rinsed for $10 \mathrm{~min}$ with PBS, incubated for another $30 \mathrm{~min}$ with the second (conjugated) antibody, and rinsed again in PBS for $10 \mathrm{~min}$. The RAM-PO was diluted $1: 100$ in PBS containing 5\% non-immune human serum (NHS) and $5 \%$ non-immune rabbit serum (NRS). The SWAR-PO was diluted 1:100 in PBS containing $5 \%$ NHS and 5\% NSS. Antibody localization was visualized by incubation of sections with a TRIS-buffered saline solution (0.05 M, pH7.4) containing $50 \mathrm{mg} \mathrm{3,3} \mathrm{diamino}$ benzidine tetrahydrochloride (Fluka, FRG) and $0.03 \%$ hydrogen peroxide. Slides were then washed in running tapwater, counterstained with Hematoxylin and mounted in malinol.

Positive controls for the detection of estradiol, progesterone and testosterone consisted of sections of ovaries containing follicles and copora lutea, and testis, respectively.

\section{Electron microscopy}

Two granulosa cell tumours were examined by electron microscopy. Frozen tumour tissue was diced in 1-2 mm cubes and placed in $4 \%$ formaldehyde and $1 \%$ glutaraldehyde. All tumour tissue was washed in phosphate buffer and postfixed in 1\% osmium tetroxide. Samples were dehydrated through graded alcohols and embedded in Epon. Semithin sections $(0.5-1 \mu \mathrm{m}$ thick) were stained in Toludine Blue; selected blocks were thin-sectioned with diamond knives, mounted on 200 mesh grids, and
Table 1. Commercial source of antibodies used

\begin{tabular}{lll}
\hline Antibodies & & Commercial source \\
\cline { 1 - 1 } $\begin{array}{l}\text { rabbit anti-estradiol } \\
\text { rabbit anti-testosterone }\end{array}$ & & Ortho Diagnostics \\
rabbit anti-progesterone & & Diagnostic Product Corp. \\
mouse anti-progesterone & Unipath \\
rabbit anti-progesterone & Chemicon \\
\hline
\end{tabular}

contrasted with uranyl acetate and lead citrate. Grids were examined in a Philips EM 201 electron microscope.

\section{Determination of tissue steroid level}

To evaluate the significance of immunohistochemical reactions for steroid hormones, particularly estradiol, this steroid was estimated by means of radioimmunoassay in four ovarian tissues (two granulosa cell tumours, one theca and one ovary with hyperthecosis), before and after dehydration. Evaluations were performed directly on snap frozen tissue, as well as after thawing and fixing samples of the same tissue in buffered formalin, dehydration in alcohol and storage in toluene for $24 \mathrm{~h}$. The toluene was then allowed to evaporate at room temperature. For radioimmunoassay, the tissues were cut into small pieces $\left(1 \mathrm{~mm}^{3}\right)$, homogenized in glass/glass potter-type homogenizers, and finally sonicated. Acetone was added to precipitate proteins, and the acetone water layer was dried until only water remained. The water layer was extracted with ether and subsequently ether was evaporated. Then, $1 \mathrm{ml}$ of estradiol-free human serum was added to the residue, and the estradiol concentration in the sample was estimated by radioimmunoassay using kits commercially obtained from Diagnostics Product Corporation L(DPC), Los Angeles, USA.

\section{Results}

Table 2 shows the clinical and immunohistochemical findings in 25 patients with granulosa cell tumours. Similar findings in six patients with ovarian carcinomas have been listed in Table 3 .

\section{LIGHT MICROSCOPY}

Twenty-five of the 31 neoplasms had the histological appearance characteristic of granulosa cell tumour. Fifteen of these neoplasms were pure granulosa cell tumour; the remaining ten contained a minor theca cell component. The granulosa cells had a scanty cytoplasm and round or ovoid nuclei, often with indented nuclear membrane suggestive of a 'coffeebean' appearance. In almost all tumour cells, a small nucleolus was seen. A variety of histological patterns were present, the diffuse pattern being the most frequently observed. Call-Exner bodies were seen primarily in the microfollicular pattern as small spaces containing dense eosinophilic material or nuclear fragments. The remaining six neoplasms were poorly differentiated tumours composed of solid areas lacking 'coffee-bean' nuclei. 
Table 2. Clinical and immunohistochemical findings in patients with granulosa cell tumour

\begin{tabular}{|c|c|c|c|c|c|}
\hline $\begin{array}{l}\text { Patient } \\
\text { number }\end{array}$ & Age & Estradiol & Progesterone & Testosterone & Endometrium \\
\hline 1 & 37 & ++ & + & + & \\
\hline 2 & 47 & + & + & - & \\
\hline 3 & 58 & ++ & ++ & ++ & Carcinoma \\
\hline 4 & 58 & + & + & - & Hyperplasia \\
\hline 5 & 50 & + & + & - & \\
\hline 6 & 39 & + & + & - & \\
\hline 7 & 53 & \pm & + & - & Proliferative \\
\hline 8 & 20 & ++ & + & + & \\
\hline 9 & 51 & + & + & - & Proliferative \\
\hline 10 & 53 & + & + & - & Proliferative \\
\hline 11 & 75 & + & + & - & \\
\hline 12 & 32 & $+t$ & + & - & \\
\hline 13 & 52 & + & + & + & \\
\hline 14 & 61 & + & + & + & Hyperplasia \\
\hline 15 & 61 & ++ & + & - & Hyperplasia \\
\hline 16 & 27 & ++ & + & - & \\
\hline 17 & 66 & + & + & ++ & Hyperplasia \\
\hline 18 & 46 & + & + & + & Proliferative \\
\hline 19 & 37 & \pm & + & ++ & \\
\hline 20 & 68 & + & + & + & \\
\hline 21 & 58 & + & + & + & Hyperplasia \\
\hline 22 & 62 & + & + & ++ & \\
\hline 23 & 51 & + & + & + & Hyperplasia \\
\hline 24 & 54 & - & + & - & \\
\hline 25 & 56 & + & + & + & Hyperplasia \\
\hline
\end{tabular}

\section{STEROID LOCALIZATION}

Twenty-four of the 25 granulosa cell tumours tested for estradiol showed positivity (Fig. 1), predominantly in the granulosa cells but also in theca cells. The six poorly differentiated carcinomas were negative for estradiol. All 25 tumours tested for progesterone using one of the commercially obtained antisera were positive (Fig. 2), while the other two failed to achieve a reproducible staining reaction. Sixteen of the 25 granulosa cell tumours tested for testosterone were only moderately positive (Fig. 3), compared to the staining intensity achieved with antibodies to estradiol and progesterone. The stromal component also showed staining by antisera directed against the three steroids, although in most cases this was less intense than that of the granulosa cells.

\section{Associated endomaterial changes}

In 13 cases of granulosa cell tumour, endometrium was available for examination. In eight patients, hyperplasia of the endometrium was present, and in one patient an adenocarcinoma was detected. In the remaining four cases proliferative activity of the endometrium was present. Table 4 shows the combined data of steroid immunohistochemistry of granulosa cell tumour and endometrial histopathology.
Table 3. Clinical and immunohistochemical findings in patients with undifferentiated ovarian carcinoma

\begin{tabular}{lllll}
\hline $\begin{array}{l}\text { Patient } \\
\text { number }\end{array}$ & Age & Estradiol & Progesterone & Testosterone \\
\hline 26 & 41 & - & + & + \\
27 & 41 & - & + & + \\
28 & 69 & - & + & + \\
29 & 73 & - & + & - \\
30 & 74 & - & - & - \\
31 & 53 & - & + & - \\
\hline
\end{tabular}

Table 4. Correlation of immunohistochemical results and endometrial findings

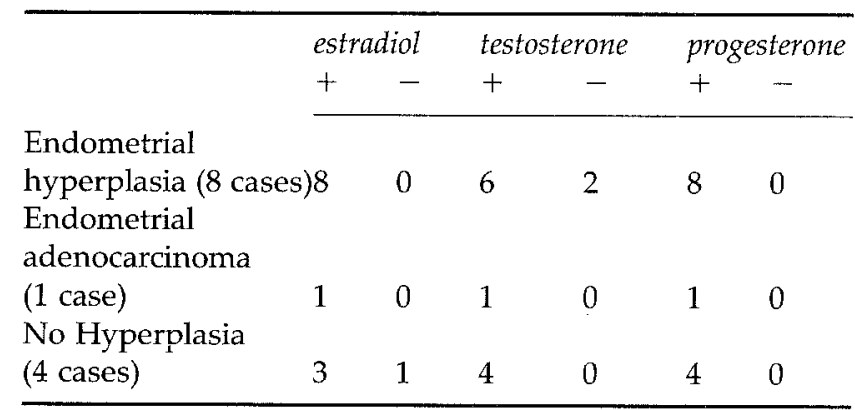



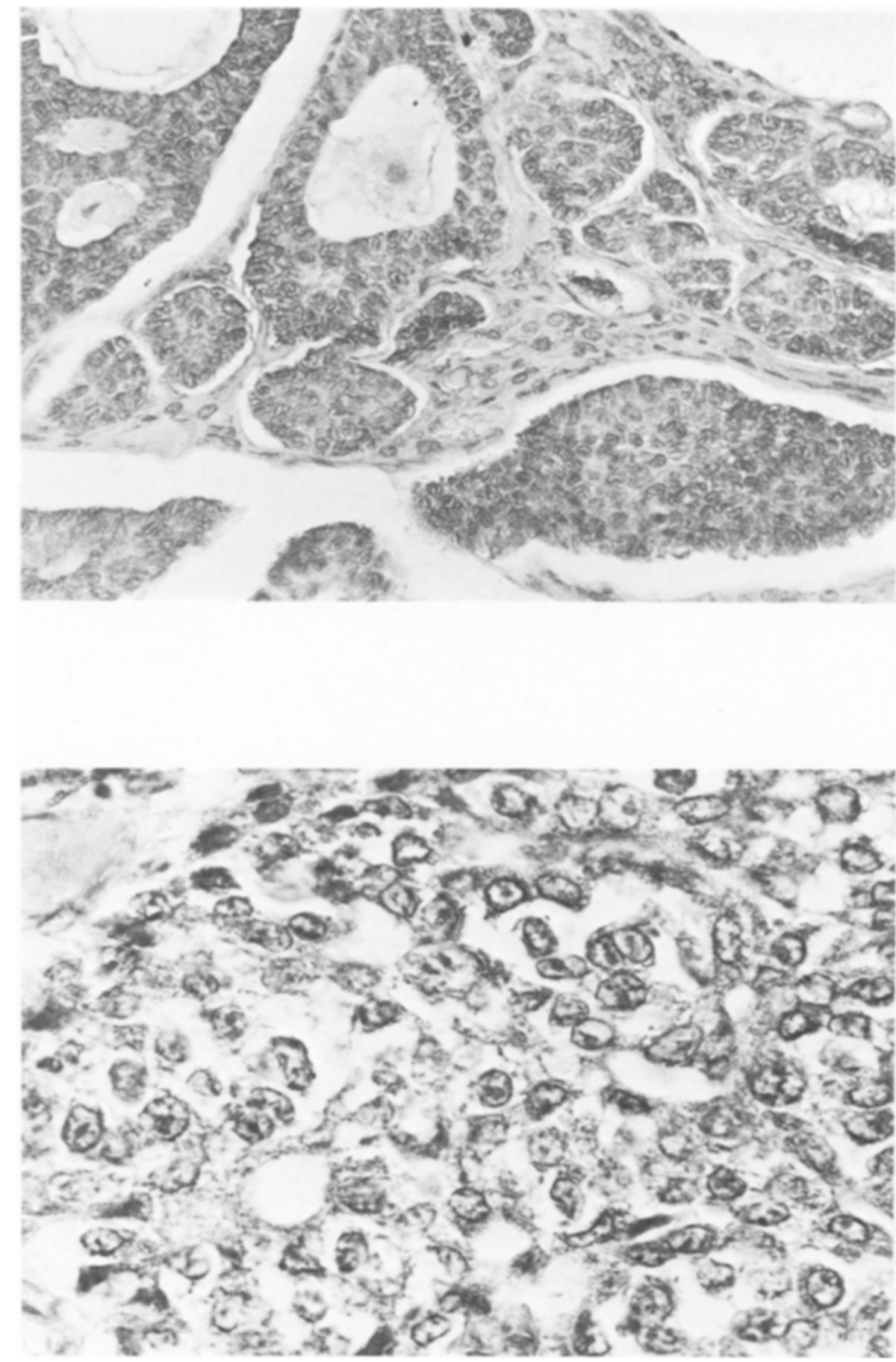

Fig. 1. (top) Granulosa cell tumour: immunoperoxidase estradiol showing diffuse positivity of granulosa cells, but also theca cells with a high background staining. $\times 380$.

Fig. 2. Granulosa cell tumour: immunoperoxidase progesterone showing diffuse positivity of granulosa cells. $\times 600$.

Effect of tissue dehydration during tissue processing on estradiol content in ovarian tumours

Determination of estradiol was performed by radioimmunoassay on ovarian tissues (see p. 270). The results indicate that, in all cases, the dehydration procedure leads to drastic reduction in estradiol content to levels below the detection limit of radioimmunoassay (Table $5)$.

\section{ELECTRON MICROSCOPY}

The cells in granulosa cell tumours were polygonal, with ovoid nuclei, showing a typical single longitudinal indentation corresponding to the 'coffee-bean' appearance. The cytoplasm was scanty. Wide intercellular spaces and tight junctions were present. The cytoplasm in most cases contained few organelles. Call-Exner bodies were identified focally as hollow 


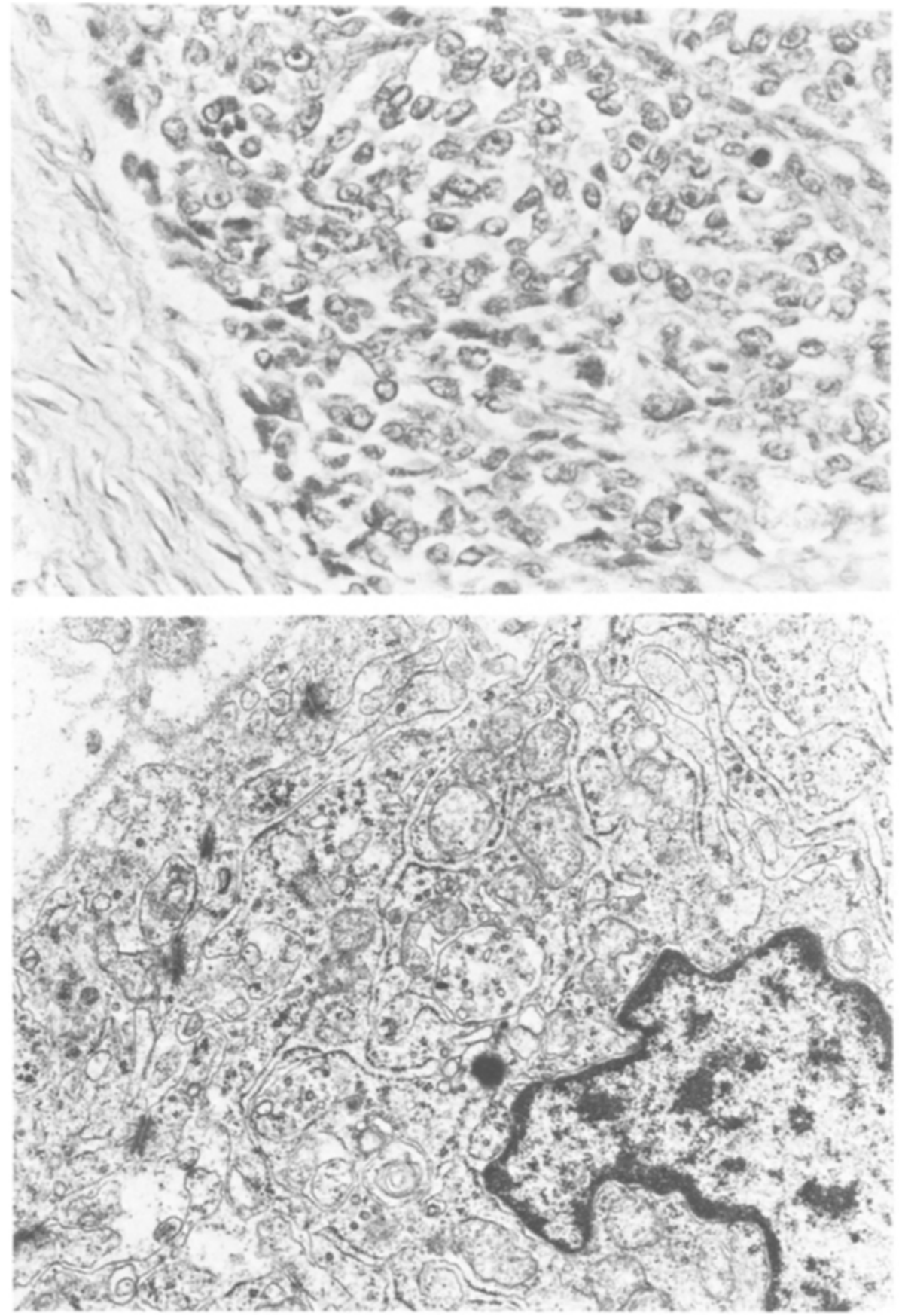

Fig. 3. (top) Granulosa cell tumour: immunoperoxidase testosterone showing positivity of granulosa cells, but also stroma cells. $\times 380$.

Fig. 4. Granulosa cell tumour: part of cytoplasm containing abundant smooth endoplasmic reticulum and mitochondria with tubular cristae. $\times 8000$.

Table 5. Effect of dehydration on tissue estradiol content

\begin{tabular}{|c|c|c|}
\hline & $\begin{array}{l}\text { estradiol content } \\
\text { not dehydrated }\end{array}$ & $\begin{array}{l}\text { pmol/gram) } \\
\text { dehydrated }\end{array}$ \\
\hline Hyperthecosis & 120 & $<0.35^{*}$ \\
\hline Thecoma & 0.37 & $<0.23$ \\
\hline Granulosa cell tumour I & 3.3 & $<0.04$ \\
\hline Granulosa cell tumour II & 1.8 & $<0.02$ \\
\hline
\end{tabular}

${ }^{*}$ Figures represent the detection limits of the radioimmunoassay for the particular specimens. intercellular spaces surrounded by neoplastic cells. Between $1 \%$ and $15 \%$ of cells were characterized by moderate to abundant smooth endoplasmic reticulum and larger mitochondria with tubular cristae, considered to be characteristic of steroid production (Fig. 4).

\section{Discussion}

We have investigated the immunohistochemical staining of 25 ovarian granulosa cell tumours using 
antibodies against estradiol, progesterone and testosterone. Twenty-four of the 25 tumours stained for estradiol predominantly in granulosa cells, but also in theca cells. In a number of previous papers, Kurman et al. $(1978,1979,1984)$ reported immunohistochemical localization of steroids in gonadal stromal tumours. The relative intensity of staining reaction led these authors to conclude that granulosa cells and not theca cells are primarily responsible for estrogen production. Their results support the feasibility of this technique, as do ours. We noticed a high background staining similar to that reported by Kurman et al., which could be attributed to the solubility of steroid hormones leading to ready diffusion throughout the tissue.

A severe drawback of the commercially obtained antisera is that multiple batches of such antisera showed highly variable results ranging from strongly positive to negative. This appeared to be the case particularly for the anti-progesterone antisera. Regarding the specificity of antisera directed against progesterone and testosterone, it was striking that three out of five undifferentiated carcinomas showed a positive staining reaction. In addition, the antisera directed against testosterone and progesterone also showed positive staining with other tissues, e.g. intestinal epithelium (data not shown). In accordance with previous ultrastructural studies (MacCaulay, et al., 1967; Gondos, 1969; Toker, 1968; Pederson \& Larsen, 1970; Klemi \& Gronroos, 1979; Gaffney et al., 1983; Salazar \& Gonzales-Angulo, 1984), we observed that the granulosa cell tumours were predominantly composed of poorly differentiated cells. In the two tumours investigated, only a few cells $(1-15 \%)$ contained a moderate to abundant smooth endoplasmic reticulum and mitochondria with tubular cristae. These latter features are considered to be characteristic of steroid synthesis. This finding is in contrast with the observed diffuse immunohistochemical staining pattern for estradiol, progesterone and testosterone.

In our series, histopathological information on the endometrium was available in 13 of the 25 cases of granulosa cell tumour. Eight had an endometrial hyperplasia, one had endometrial carcinoma, and in four cases the endometrium showed proliferative activity. Kurman et al. (1979) studied 11 cases of granulosa theca tumours, out of which nine had an endometrial hyperplasia, one had an endometrial polyp, and in one case no endometrial sample was available. In all 11 cases, the presence of steroids was demonstrated in granulosa cells using immunohistochemistry. Accordingly, Gaffney et al. (1983) demonstrated the presence of estradiol in ten out of 11 granulosa cell tumours: six had an hyperplastic endometrium, two cases showed endometrial proliferation, and in one case an endometrial polyp was found. In the remaining two cases no endometrium was available. In our series, however, a positive staining reaction for estradiol was not related to the presence of endometrial hyperplasia of carcinoma (Table 4). This apparent lack of biological significance of immunohistochemical staining reactions for estradiol can be explained in three ways:

1. The endometrium has a diminished hormone sensitivity in a proportion of the patients;

2. Estradiol present in some granulosa cell tumours is not secreted in sufficient amounts in order to lead to endometrial pathology;

3. In reality, what we detect by using the antiestradiol antiserum is a cross-reacting compound which differs from estradiol.

The data derived from the biochemical estimation of tissue steroids show that organic solvents lead to a drastic reduction of estradiol content. The very low level of steroids (Table 5) remaining in the tissue after extraction by organic solvents is less likely to be detected by immunohistochemical technique. The diffuse staining pattern makes it even more unlikely that these minute amounts of steroids were indeed detected by the employed immunohistochemical staining procedure. A possible explanation of positive immunohistochemical results could be the presence of a protein-bound fraction of steroids which can not be extracted from the tumour tissue by radioimmunoassay, but is detected by the antibody in situ. This possibility should be regarded as unlikely in view of the results of De Jong et al. (1974). These authors showed that after the extraction procedure, as employed in the present study, only $7 \%$ of estradiol was left behind in testicular tissue, even though this tissue contains estradiol receptors. Another possibility is that the anti-estradiol antiserum is directed against antigenic determinants shared by the estradiolprotein complex, used as immunogen, and another (non-related) tissue protein. It has been reported previously that staining of frozen sections for estradiol generally leads to very high background staining (Kurman et al., 1981), and therefore we did not attempt to immunostain frozen sections as a control for the analysis by radioimmunoassay.

To our knowledge, none of the previous authors have performed biochemical assays for tissue steroid level to confirm their immunohistochemical observations.

In conciusion, the data of this study cast serious doubt on the feasibility of the use of the immunohistochemical technique for detection of steroids on paraffin-embedded tissues. This view is strengthened by the observation that no relationship exists between immunoreactivity of a granulosa cell tumour for estradiol and the presence of endometrial histopathology, i.e. hyperplasia or adenocarcinoma. 


\section{Acknowledgements}

The authors wish to thank Mrs M. Hanegraaff for secretarial help, and Mrs P. Delfos for photography.

\section{References}

DE JONG, F. H., HEY, A. H. \& VAN DER MOLEN, H. J. (1974) Oestradiol-17 $\beta$ and testosterone and production in vitro. J. Endocr. 60, 409-19.

FOX, H., AGRAWAL, K. \& LANGLEY, F. A. (1975) A clinicopathological study of 92 cases of granulosa cell tumour of the ovary with special reference to the factors influencing prognosis. Cancer 35, 231-41.

Fox, H. (1985) Sexcord-stromal tumours of the ovary. $J$. Pathol. 145, 127-48.

GAFFNEY, E. F., MAJUMDAR, B., HERTZLER, G. L., ZANE, R., FURLONG, B. \& BREDING, E. (1983) Ovarian granulosa cell tumors: immunohistochemical localization of estradiol and ultrastructure, with functional correlations. Obstet. Gynecol. 61, 311-19.

GIUNTOLI, R. L., CELEBRE, J. A., WU, C. H., WHEELER, H. \& MIKUTA, J. J. (1976) Androgenic function of a granulosa cell tumor. Obstet. Gynecol. 47, 77-9.

GONDOS, B. (1969) Ultrastructure of a metastatic granulosatheca cell tumor. Cancer. 24, 954-9.

JARABAK, J. \& TALERMAN, A. (1983) Virilization due to metastasizing granulosa cell tumor. Int. J. Gynecol. Pathol. 2, 316-24.

KLEMI, P. J. \& GRONROOS, M. (1979) An ultrastructural and clinical study of theca and granulosa cell tumors. Int. J. Gynecol. Obstet. 17, 219-25.

KURMAN, R. J., ANDRADE, D., GOEBELSMANN, U. \& TAYLOR, C. R. (1978) An immunohistological study of steroid localization in Serotli-Leydig tumors of the ovary and testis. Cancer 42, 1772-83.

KURMAN, R. J., GOEBELSMANN, U. \& TAYLOR, C. R. (1979) Steroid localisation in granulosa theca tumor of the ovary. Cancer 43, 2377-84.
KURMAN, R. J., GOEBELSMANN, U. \& TAYLOR, C. R. (1981) Localisation of steroid hormones in functional ovarian tumors. In Diagnostic Immunohistochemistry. Masson Monographs in Diagnostic Pathology pp. 137-48. New York: Masson Publishing

KURMAN, R. J., GANJEI, P. \& NADJI, M. (1984) Contributions of immunohistochemistry to the diagnosis and study of ovarian neoplasms. Int. J. Gynecol. Pathol. 3, 326.

MACCAULAY, M. A., WELIKY, I. \& SCHULZ, R. A. (1976) Ultrastructure of a biosynthetically active granulosa cell tumor. Lab. Invest. 17, 562-70.

NISHI, K. TOKUNAGA. A., SHIMIZU, Y., YOSHIYUKI, $T_{\text {, }}$ WADA, M., MATSUKURA, N., TANAKA, N., ONDA, M. \& ASANO, G. (1987) Immunohistochemical study of intracellular estradiol in human gastric cancer. Cancer 59, 1328-32.

NORRIS, H. J. \& TAYLOR, H. B. (1969) Virilisation associated with cystic granulosa cell tumors. Obstet. Gynecol. 34, 629-35.

PEDERSON, P. H. \& LARSON, J. F. (1970) Ultrastructure of a granulosa cell tumor. Acta. Obstet. Gynecol. Scand. 49, 105-10.

SALAZAR, H. \& GONZALEZ-ANGULO, A. (1984) Ultrastructural diagnosis in gynecological pathology. Clin. Obstet. Gynecol. 11, 25-77.

SCULLY, R. E. (1977) Estrogen and endometrial carcinoma. Hum. Path. 8, 481-83.

SCULLY, R. E. (1979) Tumors of the ovary and maldeveloped gonads. In Atlas of tumor pathology. 2nd series, fascicle no. 16. Washington DC: Armed Forces Institute of Pathology.

TOKER, C. (1968) Ultrastructure of a granulosa cell tumor. Am. J. Obstet. Gynecol. 100, 779-84.

WILANSKY, D. L., SCOTT, B. H. \& LACHANGE, R. C. (1976) Masculinizing granulosa cell tumor. Can. Med. Assoc. J. 115, 545-6.

YOUNG, R. H. \& SCULLY, R. E. Ovarian sexcord-stromal tumors: recent advances and current status. Clin. Obstet. Gynecol. 11, 93-134. 